\title{
L'arme du crime était dans les cheveux !
}

\section{The murder weapon was found in the hair!}

\section{Jean-Pierre GOULLE ${ }^{(1)^{*}}$, Loïc MAHIEU ${ }^{(1)}$, Pascal KINTZ ${ }^{(2)}$}

(1) Laboratoire de Pharmacocinétique et de Toxicologie Cliniques, Groupe Hospitalier du Havre, LE HAVRE - France

(2) Laboratoire ChemTox, ILLKIRCH - France

*Corresponding Author: Jean-Pierre GOULLÉ, Laboratoire de Pharmacocinétique et de Toxicologie Cliniques, Groupe Hospitalier du Havre - BP 24 - 76083 LE HAVRE Cedex - France Tél : 0232733223 - Fax : 0232733238 - E-mail : jgoulle@ch-havre.fr

(Reçu le 7 novembre 2005 ; accepté le 17 décembre 2005)

\section{RÉSUMÉ}

Une femnie de 64 ans décède rapidement après son hospitalisation. Deux jours plus tard, son époux, âgé de 66 ans meurt également après son transfert dans le service de réanimation d'un autre hôpital. Après spéciation, les dosages d'arsenic minéral et organique par spectrométrie d'absorption atomique sans flamme dans les milieux biologiques permettent d'attribuer ces deux décès à une intoxication arsenicale. Le dosage de l'arsenic dans les cheveux du couple, ainsi que dans ceux du suspect des meurtres montre qu'ils renferment tous de l'arsenic. Pour l'époux, l'intoxication datait depuis au moins onze mois, alors qu'elle n'était que de deux ou trois mois pour son épouse. Une exposition à l'arsenic contemporaine des décès est également mise en évidence chez le suspect. De plus, chez ce dernier; des prélèvements de cheveux effectués 2, 5 et 8 mois après le crime ont permis de quantifier la vitesse de pousse des cheveux et la perte moyenne d'arsenic au cours de cette période de 6 mois. Le suspect a été confondu en raison de la présence d'arsenic dans ses cheveux et sur ses vêtements personnels: l'arme du crime était dans les cheveux.

\section{SUMMARY}

A 64 year old woman died shortly after she was admitted to hospital. Two days later her husband, 66 years old, also died in the ICU of another hospital. These two fatalities were attributed to arsenic poisoning based on mineral and organic biological fluids As speciation, which was achieved by flameless atomic absorption spectrometry. The deceased and the murder suspect's As hair analysis were assessed. All were positive. The husband was intoxicated with As for a period of at least 11 months, whereas it was only of 2 or 3 months duration for his wife. As exposure during this period could be demonstrated for the murder suspect. Moreover; for this individual a number of hair strands were cut 2, 5 and 8 months after the crime. Therefore we were able to measure the As washed out from the hair taking into consideration the average growth during this 6 month period: We were also asked to assess arsenic in the suspect's clothing : the murder weapon was found in the hair: 


\section{Introduction}

Arsenic poisonings are still significant in the field of toxicology, although they do not occur as frequently as they did 40 years ago. Arsenic-induced deaths have been known to occur from intentional poisonings in suicides and homicides and sometimes from accidental poisoning (1-8). Accidental poisonings appear to be most common in children (9-12), whereas intentional and covert poisonings predominate in adults. Most acute poisonings are fatal, although in some cases patients have recovered. Blood and hair are respectively the preferred specimens for the diagnosis of acute and chronic arsenic exposures. The toxicologist may differentiate acute from chronic poisoning. The pattern of arsenic exposure may be determined by sequential analysis of hair sections. Hair grows about $1 \mathrm{~cm}$ per month, therefore analysis of $1 \mathrm{~cm}$ segments provides a pattern of monthly exposure. Due to the high affinity to sulfhydryl groups, arsenic is readily fixed by the hair. Arsenic concentrations in hair are higher compared with those in tissues. Most of the arsenic in hair occurs in the trivalent inorganic form As (III) (13). Intake of organic arsenic compounds via seafood is not reflected by the hair (14).

\section{Materials and method}

\section{Case reports}

A 64-year old woman died shortly after she was admitted to hospital. Two days later, her husband, 66-years old, also died in the intensive care unit of another hospital. These two fatalities were attributed to arsenic poisoning. Mineral and organic biological fluids arsenic speciation were achieved and quantitated by flameless atomic absorption spectrometry (Table I). Post-mortem hair samples were collected for both deceased. The hair length was $11 \mathrm{~cm}$ for the man and $9 \mathrm{~cm}$ for the woman. For the murder suspect, a number of hair strand samples were cut 2, 5 and 8 months after the crime, over a 6-month period. Beard hair was also with the final hair specimen. Arsenic analysis of clothes worn by this individual was positive. Furthermore, hair samples were obtained from five neighbours of the deceased couple.

\section{Toxicological analysis}

Hair samples were examined for arsenic using flameless atomic absorption spectrometry. Hair specimens were decontaminated according to the following procedure: acetone ( $5 \mathrm{~mL}, 2 \mathrm{~min}$ ), warm water $(5 \mathrm{~mL}, 2 \mathrm{~min}$ ) and finally acetone $(5 \mathrm{~mL}, 2 \mathrm{~min})$, with horizontal shaking. After sequential analysis of sections $(1,2$ or 3 $\mathrm{cm}$ ) and weighting (20 to $50 \mathrm{mg}$ ) alkaline hydrolysis was performed with sodium hydroxide, $\mathrm{M}$ at $90^{\circ} \mathrm{C}$ for 30 minutes. Neutralisation was achieved with a small acid excess of $1.03 \mathrm{M}$ nitric acid. Before testing by atomic absorption, nickel nitrate at $6 \mathrm{~g} / \mathrm{L}$ of nickel was added. Total arsenic was measured by graphite furnace atomic absorption spectrometry with a reading at $193.7 \mathrm{~nm}$, including a window at $0.5 \mathrm{~nm}$, using a Varian Spectra AA-800 system, equipped with Zeeman Background Correction.

Tableau I: Total and mineral arsenic in the blood of the two deceased.

\begin{tabular}{|c|c|c|c|}
\hline \multirow{2}{*}{ Husband } & Blood & $\begin{array}{c}\text { Total As } \\
(\mathbf{N}<60 \mu \mathrm{g} / \mathrm{L})\end{array}$ & $\begin{array}{c}\text { Mineral As } \\
(\mathbf{N}<20 \mu \mathrm{g} / \mathrm{L})\end{array}$ \\
\cline { 2 - 4 } & Heart & 1227 & 1174 \\
\hline \multirow{2}{*}{ Wife } & $\begin{array}{c}\text { Peripheral } \\
\text { (exhumation) }\end{array}$ & 579 & 463 \\
\cline { 2 - 4 } & $\begin{array}{c}\text { Heripheral } \\
\text { (exhumation) }\end{array}$ & 21,765 & - \\
\hline
\end{tabular}

\section{Results and discussion}

Using a 2-mg sample, the response of the machine was linear from 0.5 to $120 \mathrm{ng}$ arsenic per $\mathrm{mg}$ of hair. Under these conditions, the limit of detection of the system was $0.11 \mathrm{ng} / \mathrm{mg}$. Intra-assay precision, evaluated with 20 consecutive analyses was $9.7 \%$. For the deceased couple neighbours', the hair arsenic content was within normal values, ranging from 0.36 to $0.69 \mathrm{ng} / \mathrm{ml}$. For the couple and the murder suspect, results of toxicological investigations are reported Table II and Table III. For the two deceased individuals, the hair results were consistent with chronic exposure to mineral arsenic as most of the arsenic in hair occurs in the trivalent inorganic form (13). This is due to the very slow biological fluid arsenic decrease after mineral exposure. Once an individual is isolated from exposure, hair values return to normal within several weeks (15). This is also due to the high affinity of arsenic to sulfhydryl groups leading to a significant level of incorporation into the hair (13). The organic arsenic compounds via seafood are rapidly eliminated from the body; therefore intake of organic arsenic is not reflected in the hair. Hair arsenic results (Table $\mathrm{II}$ ) are in accordance with arsenic poisoning for nearly a year and at least 11 months for the husband, but only 2 or 3 months for the wife. Arsenic concentration in the hair of the murder suspect (Table III) was consistent with a regular exposure of this individual to As (III). For the suspect, the results of the three hair collections (2,5 and 8 months after the 
crime) demonstrate that the highest arsenic concentration was present at the time the couple was murdered, in October 2001. These three hair collections were sufficient to measure a $6 \mathrm{~cm}$ hair growth for a 6 month period (i.e. $1 \mathrm{~cm}$ per month). We could also determine the hair arsenic wash out during this 6 month period. It was not linear, but approximately $20 \%$ average loss per month was established. The arsenic concentration in the beard hair of the murder suspect are reported in Table IV. The results are very similar to those obtained from the hair and the highest concentration was observed in the oldest segment of the beard hair.

Table II : Arsenic concentration in hair of the couple.

\begin{tabular}{|c|c|c|}
\hline \multicolumn{3}{|c|}{ Hair As (ng/mg) $-\mathrm{N}=0.1 .1 .0 \mathrm{ng} / \mathrm{mg}$} \\
\hline & WLE & HUSBAND \\
\hline $1 \mathrm{~cm}(\mathrm{IOOt})$ & \multirow{2}{*}{108.7} & 293.6 \\
\hline $1 \mathrm{~cm}$ & & 142.9 \\
\hline $1 \mathrm{~cm}$ & \multirow{2}{*}{6.5} & 43.3 \\
\hline $1 \mathrm{~cm}$ & & 27.6 \\
\hline $1 \mathrm{~cm}$ & \multirow{2}{*}{1.0} & 21,4 \\
\hline $2 \mathrm{~cm}$ & & 18.1 \\
\hline $2 \mathrm{~cm}$ & 1.3 & 13.0 \\
\hline $2 \mathrm{~cm}$ (end) & - & 13.4 \\
\hline
\end{tabular}

Table III : Arsenic concentration in hair of the murder suspect.

\begin{tabular}{|c|c|c|c|c|c|}
\hline & Segment & $\begin{array}{l}\text { Hair As } \\
\text { (ng/mg) }\end{array}$ & Period & & \\
\hline \multirow{8}{*}{$\begin{array}{l}11 \mathrm{~cm} \text { hair } \\
\text { collection } \\
06-20-02\end{array}$} & \multirow[t]{2}{*}{$2 \mathrm{~cm}$ (root) } & \multirow[t]{2}{*}{0.81} & 20 jun. 2002 & & \\
\hline & & & 20 apr. 2002 & & \multirow[t]{2}{*}{ Segme } \\
\hline & \multirow[b]{2}{*}{$2 \mathrm{~cm}$} & \multirow[b]{2}{*}{1.04} & 20 apr. 2002 & & \\
\hline & & & 20 feb. 2002 & \multirow{5}{*}{$\begin{array}{l}8 \mathrm{~cm} \text { hair } \\
\text { collection } \\
03-23-02\end{array}$} & \multirow[t]{2}{*}{$2 \mathrm{~cm}$ (ro } \\
\hline & \multirow{2}{*}{$2 \mathrm{~cm}$} & \multirow{2}{*}{1.23} & 20 feb. 2002 & & \\
\hline & & & 20 dec. 2001 & & $2 \mathrm{~cm}$ \\
\hline & $2 \mathrm{~cm}$ & 1.83 & 20 dec. 2001 & & $2 \mathrm{~cm}$ \\
\hline & $3 \mathrm{~cm}$ (end) & 1.90 & 20 jul. 2001 & & $2 \mathrm{~cm}(\mathrm{en}$ \\
\hline \multicolumn{2}{|c|}{$\begin{array}{l}\text { Table IV : Arsenic } \\
\text { murder suspect. }\end{array}$} & ncent & $n$ in th & eard $h$ & of the \\
\hline \multicolumn{2}{|l|}{$\ldots$} & \multicolumn{2}{|c|}{ Segment } & \multicolumn{2}{|c|}{ Beard hair As (ng/mg) } \\
\hline \multirow{5}{*}{\multicolumn{2}{|c|}{$\begin{array}{c}10 \mathrm{~cm} \\
\text { beard hair collection } \\
06-23-2002\end{array}$}} & \multicolumn{2}{|c|}{$2 \mathrm{~cm}$ (root) } & \multicolumn{2}{|l|}{0.91} \\
\hline & & \multicolumn{2}{|c|}{$2 \mathrm{~cm}$} & \multicolumn{2}{|l|}{1.19} \\
\hline & & \multicolumn{2}{|c|}{$2 \mathrm{~cm}$} & \multicolumn{2}{|l|}{1.30} \\
\hline & & \multicolumn{2}{|c|}{$2 \mathrm{~cm}$} & \multicolumn{2}{|l|}{1.35} \\
\hline & & \multicolumn{2}{|c|}{$2 \mathrm{~cm}$ (end) } & 1.84 & \\
\hline
\end{tabular}

\section{Conclusion}

Using flameless atomic absorption spectrometry, arsenic hair analysis was extremely useful to complete blood, gastric and bile determinations in a double fatal arsenic poisoning. The hair analysis was able to specifically document the period of high metalloid exposure for the couple. It also demonstrates by hair and beard hair analysis a lower but consistent contact with this element for the murder suspect. The murder weapon was found in the hair!

\section{Acknowledgements:}

The authors are most grateful to Richard Medeiros, Rouen University Hospital Medical Editor, for his expert advice in editing the manuscript. 


\section{References}

1. J.P. Goullé. Métaux. In Toxicologie et pharmacologie médicolégales, P. Kintz, Ed. Elsevier, Paris, 1998, pp 189232.

2. T. Lech, and F. Trela. Massive acute arsenic poisonings. Forensic Sci. Int. 151: 273-277 (2005).

3. L. Gerhardsson, E. Dahlgren, A. Eriksson, B.E. Lagerkvist, J. Lundstrom, and G.F. Nordberg. Fatal arsenic poisoning - a case report. Scand. J. Work Environ. Health. 14: 130-132 (1988).

4. E. W. Massey, D. Wold, and A. Heyman. Arsenic : homicidal intoxication. South Med. J. 77: 848-851 (1984).

5. M. A. Mackell, G. E. Gantner, A. Poklis, and M. Graham. A suspected arsenic poisoning murder disclosed by forensic autopsy. Am. J. Foren. Med. Pathol. 6: 358-361 (1985).

6. A. Poklis, and J. J. Saady. Arsenic poisoning : acute or chronic ? Suicide or murder ? Am. J. Foren. Med. Pathol. 11: 226-232 (1990).

7. J. H. Embry, and H. C. Walls. Serial arsenic poisoning : two Alabama cases. Alabama Med. 59: 4-28 (1990).

8. C. Lacroix, E. Legendre, J. Anagnostides, J.P. Goullé, J.P. Rigaud and J. Nouveau. Intoxication volontaire mortelle à l'arsenic. Journées internationales de toxicologie hospitalière, Liège, 22-23 Octobre (1998).

9. J.P. Goullé, C. Kolly, C. Lacroix, A. Duquenoy, G. Gaussin and B. Leluyer. Intoxication accidentelle à l'arsenic par une pierre de collection. Ann. Toxicol. Anal. 13: 30-34 (2001).

10.L. Fourtes. Arsenic poisoning. Ongoing diagnostic and social problem. Postgrad. Med. 83: 233-234, 241-244 (1988).

11. A. F. Brayer, C. M. Callahan, and P. M. Wax. Acute arsenic poisoning from ingestion of snakes. Pediatr. Emerg. Care. 13: 394-396 (1997).

12. J. J. Saady, R. V. Blanke, and A. Poklis. Estimation of the body burden of arsenic in a child fatally poisoned by arsenite weedkiller. J. Anal. Toxicol. 13: 310-312 (1989).

13. H. C. Hopps. The biological bases for using hair and nail for analyses of trace elements. Sci. Total Environ. 7: 71-89 (1977).

14. M. Wilhelm, and H. Idel. Hair analysis in environmental medicine. Zbl. Hyg. 198: 485-501 (1996).

15 . R. J. Shamberger. Validity of hair mineral testing. Biol. Trace Element Res. 87: 1-28 (2002). 